\title{
Minireview \\ Diagnostic, prognostic and therapeutic implications of carbonic anhydrases in cancer
}

\author{
CPS Potter' and AL Harris*,I \\ 'Cancer Research UKGrowth Factor Group, Weatherall Institute of Molecular Medicine, John Radcliffe Hospital, Oxford OX3 9DS, UK
}

The carbonic anhydrases (CAs) comprise a family of evolutionarily ancient enzymes found ubiquitously in nature. They have important roles in facilitating transport of carbon dioxide and protons in the intracellular space, across biological membranes and in the unstirred layers of the extracellular space. The tumour-associated isoenzymes, CAIX and CAXII, are expressed in a wide variety of malignancies and appear to be tightly regulated by microenvironmental hypoxia. CAIX expression is linked to poor prognosis in a number of human tumours, and may be a marker of aggressive malignant phenotype and a mechanism of progression. Inhibitors of CA may inhibit tumour growth and invasion, with consequent therapeutic potential.

British Journal of Cancer (2003) 89, 2 - 7. doi:I0.I038/sj.bjc.6600936 www.bjcancer.com

(c) 2003 Cancer Research UK

Keywords: carbonic anhydrase; microenvironment; $\mathrm{pH}$; hypoxia-inducible factor

The carbonic anhydrase (CA) family of zinc metalloenzymes is phylogenetically ancient, diverse in structure and its members are found in almost every living organism (Tripp et al, 2001). This short review aims to address recent advances in the association of CA with cancer biology, with particular attention to the novel tumour-associated CAs, IX and XII.

\section{FUNCTIONS OF CA}

$$
\mathrm{H}_{2} \mathrm{O}+\mathrm{CO}_{2} \Leftrightarrow \mathrm{H}^{+}+\mathrm{HCO}_{3}^{-}
$$

The above reaction (1) is ubiquitous in nature, involving the interchange of gaseous and ionic species crucial to a wide range of physiological and biochemical processes. Biological membranes form an effective barrier to the passive diffusion of bicarbonate and hydrogen ion, whereas carbon dioxide is highly membrane permeable, and it has been suggested that CA initially evolved to facilitate trans-cellular carbon dioxide transport rather than its more familiar role in respiratory gas exchange (Henry and Swenson, 2000). Certainly, at the single-cell level, carbon dioxide diffuses more rapidly in buffer solutions and across artificial membranes than would be expected from its diffusion coefficients, and this facilitated diffusion is abolished by the inhibition of CA activity (Geers and Gros, 2000).

Carbonic anhydrase may also confer directionality on carbon dioxide transport across membranes, maintaining high levels of the gas in solution on the upstream side of the membrane, and causing acidification of the downstream boundary layer thus maintaining the concentration gradient to drive diffusion (Figure 1A).

In addition to facilitating passive diffusion, CAs may act in concert with membrane-associated ion transport systems such as the sodium-hydrogen exchanger (NHE) and chloride-bicarbonate anion exchanger (AE). Indeed, CAII is known to bind to the cytoplasmic tail of the band III AE in the erythrocyte, forming a

*Correspondence: Dr AL Harris; E-mail: aharris.lab@cancer.org.uk

Received 14 February 2003; accepted 4 March 2003 metabolon, a physically associated complex of proteins in a sequential metabolic pathway (Sterling et al, 2001) (Figure 1B).

The three distinct CA families $(\alpha, \beta$ and $\gamma)$ show no significant sequence identity and appear to have completely separate phylogenetic origins, a remarkable example of convergent evolution.

\section{THE $\alpha$-CA FAMILY}

There are 14 known members of this family, the only CAs to be found in mammalian cells. Eleven members express CA activity, whereas the three CA-related-polypeptides (CA-RPs VIII, XI and XIII) lack one or more of the critical histidine residues responsible for zinc ion binding at the active site. CAII is thought to be the most active enzyme found in nature, with a $K_{\text {cat }}$ of around $10^{6} \mathrm{~s}^{-1}$, providing near-instantaneous equilibrium between the chemical species.

The family may be subdivided, on the basis of cellular localization, into cytosolic (CAs I, II, III, VII), membrane associated (CAs IV, IX, XII, XIV), mitochondrial (CAV) and secreted (CAVI). On the basis of intron:exon relations, the cytoplasmic and mitochondrial groups seem distinct from the trans-membrane and secreted enzymes. The highly heterogeneous distribution of the various isoenzymes within tissues, organs and cells suggests functionally distinct roles in processes as diverse as acid-base balance, gas exchange, ion transport, carbon fixation and mucosal protection.

Table 1 describes the expression patterns of the cytoplasmic CAs in human tumours. It would appear that CAs I and II have some potential clinical utility as markers of differentiation for a number of cell types.

\section{NOVEL TUMOUR-ASSOCIATED TRANSMEMBRANE CAs}

\section{CAIX}

Interest in cancer-related CAs increased with the finding that the tumour-associated protein $\mathrm{MN}$, discovered in HeLa cells cocul- 
tured with breast cancer cells, contained a CA domain very similar to that of CAIV (Pastorek et al, 1994). This $54 / 58 \mathrm{kDa} \mathrm{N} N$ glycosylated transmembrane protein also has an $\mathrm{N}$-terminal region

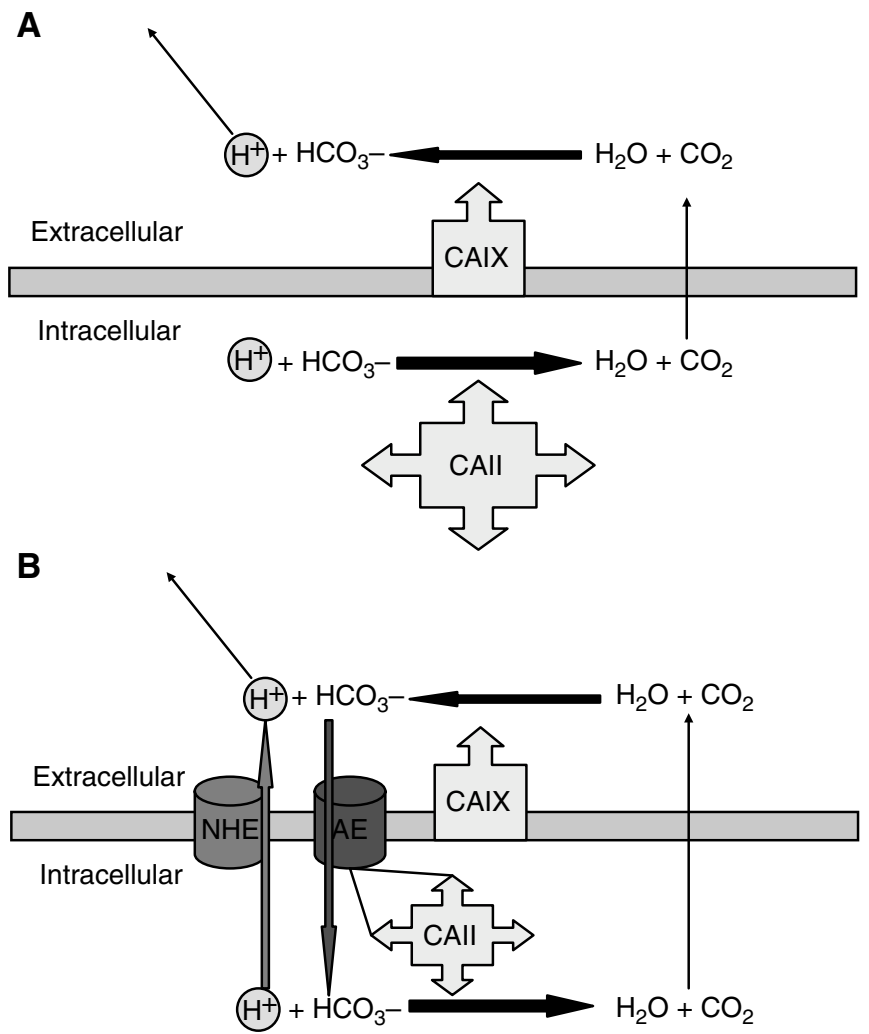

Figure I (A) Hydrogen ion produced by anaerobic metabolism within the cell must first be converted to carbon dioxide to facilitate diffusion across the lipid bilayer. This reaction with bicarbonate is catalysed by cytoplasmic CA. Once carbon dioxide has diffused into the extracellular space, CA activity in the boundary layer may regenerate protons, maintaining the carbon dioxide diffusion gradient. (B) The NHE is one method by which protons may be actively pumped from the cell. Alternatively, bicarbonate in the extracellular space (regenerated from carbon dioxide hydration with CA catalysis) may be imported into the cell via the chloride-bicarbonate AE. This bicarbonate may recombine with a proton in the cytoplasm to undertake further shuttling across the membrane. This recycling of bicarbonate with net proton extrusion is known as a Jacobs-Stewart cycle. The AE has recently been shown to bind CAll on its intracellular surface which shows significant homology to the keratan sulphate-binding domain of aggrecan (Opavsky et al, 1996), the major proteoglycan of articular cartilage, thought to be important in maintenance of tissue hydration. This pattern of a CA-related domain being found adjacent to a proteoglycan domain is also found in a number of other proteins, most notably the receptor protein tyrosine phosphatases (RPTPs $\beta$ and $\gamma$ ) and the rat neural protein, phosphacan. The CA-like domain of RPTP $\beta$ is known to act as a ligand-binding site for the neuronal cell recognition molecule contactin (Peles et al, 1995), suggesting a role distinct from catalysis for this domain.

The MN gene thus appears to be chimeric in nature, arising from exon shuffling. Its sequence has been published (Opavsky et al, 1996), the original cDNA sequence corrected (Pastorek et al, 1994) and the sequences from tumours and normal tissue shown to be identical (Pastorekova et al, 1997). In 1996, the gene was renamed CA9 and its product has shown significant CA activity when expressed in COS cells (Sly, 2000), a truncated construct even showing equivalent activity to CAII (Wingo et al, 2001). Targeted disruption of CA9 gene expression in a murine model results in gastric glandular hyperplasia with proliferation of mucus-secreting pit cells, but otherwise normal development (Gut et al, 2002).

CA9 has been suggested to be a proto-oncogene on the basis of a number of observations:

(1) Expression in HeLa cells is density dependent, CAIX expression increasing in confluent cultures (Zavada et al, 1993)

(2) In HeLa/fibroblast hybrid cell lines, tumorigenicity in nude mice correlated with CA expression levels (Pastorek et al, 1994)

(3) Transfection of NIH3T3 fibroblasts with the CA9 gene resulted in a transient transformation, with uncontrolled proliferation, growth in soft agar and morphological changes. After a few passages, the cells reverted to normal phenotype (Pastorek et al, 1994)

(4) There is differential expression of CAIX between normal tissue and tumour specimens. Immunostaining and Northern blot techniques have revealed an extremely limited distribution in normal tissues, moderate expression being found in gastric mucosa, fetal lung and muscle. More sparse expression is found in small intestine, biliary tree and the male reproductive tract. Conversely, CAIX mRNA has been found in 50 of 87 malignant cell lines in one study (Ivanov et al, 2001)

The association with gastric hyperplasia in the mouse knockout suggests that any action may be tissue specific.

Table I Expression of cytoplasmic CAs in human tumours

\begin{tabular}{|c|c|}
\hline Tumour & CA expression pattern \\
\hline Central Nervous System & $\begin{array}{l}\text { CAll staining maintained in astrocytomas, oligodendrocytomas and medulloblastomas. Staining appeared stronger in more malignant tumours } \\
\text { (Parkkila et al, 1995) }\end{array}$ \\
\hline Colorectal & $\begin{array}{l}\text { CAsl and II expression reduced as differentiation lost, with reduced immunostaining correlating with malignant progression. CAl expression } \\
\text { associated with reduced vascular invasion and good prognosis in colorectal tumours, CAll expression associated with good prognosis in rectal } \\
\text { tumours (Bekku et al, 2000). }\end{array}$ \\
\hline Lung & CAl and II expression reduced in squamous cell and adenocarcinoma (Chiang et al, 2002). \\
\hline Haematological & $\begin{array}{l}\text { CAl is a potential marker of erythroid differentiation in blast cells (Walloch et al, 1986) and CAll is found in a majority of acute leukaemias } \\
\text { (Leppilampi et al, 2002). }\end{array}$ \\
\hline
\end{tabular}

Bekku S, Mochizuki H, Yamamoto T, Ueno H, Takayama E, Tadakuma T (2000) Expression of carbonic anhydrase I or II and correlation to clinical aspects of colorectal cancer. Hepatogastroenterology 47: 998-1001

Chiang WL, Chu SC, Yang SS, Li MC, Lai JC, Yang SF, Chiou HL, Hsieh YS (2002) The aberrant expression of cytosolic carbonic anhydrase and its clinical significance in human non-small cell lung cancer. Cancer Lett I 88: 199-205

Leppilampi M, Koistinen P, Savolainen ER, Hannuksela J, Parkkila AK, Niemela O, Pastorekova S, Pastorek J, Waheed A, Sly WS, Parkkila S, Rajaniemi H (2002) The expression of carbonic anhydrase II in hematological malignancies. Clin Cancer Res 8: 2240-2245

Parkkila S, Parkkila AK, Juvonen T, Lehto VP, Rajaniemi H (1995) Immunohistochemical demonstration of the carbonic anhydrase isoenzymes I and II in pancreatic tumours. Histochem J 27: 133-138

Walloch J, Frankel S, Hrisinko MA, Weil SC (1986) Carbonic anhydrase: a marker for the erythroid phenotype in acute nonlymphocytic leukemia. Blood 68: 304-306 


\section{CAXII}

Originally patented in 1994 as a novel protein specific for lung cancer cells, CAXII is now recognised to be present in a wide variety of normal tissues and tumours (Tureci et al, 1998). The $39 \mathrm{kDa}$ transmembrane protein shows a great deal of structural homology with CAIX, but lacks the proteoglycan domain. X-ray crystallography has revealed a dimeric structure, with a characteristic active site which may be susceptible to specific inhibitors (Whittington et al, 2001). Its expression in tissues with high absorptive capacities for water (colon, collecting duct, ascending loop of Henl) suggests a role in normal tissue physiology distinct to that of CAIX (Parkkila et al, 2000a).

\section{CONTROL OF CAIX AND CAXII EXPRESSION}

A number of microenvironmental factors were initially shown to induce CAIX expression in vitro - notably confluent growth and suspension culture (Lieskovska et al, 1999).

Both CAs were shown by our group to be induced by hypoxia in a wide range of malignant cells in vitro including bladder, breast, cervical and lung cancer lines (Wykoff et al, 2000). The vonHippel-Lindau tumour suppressor gene appears to play a critical role in this process, clear cell renal carcinoma cell lines with mutant VHL expressing both CAIX and CAXII constitutively. Both RNA differential display (Ivanov et al, 1998) and RNAse protection assay (Wykoff et al, 2000) have shown that reintroduction of the wild-type VHL gene into the same cell lines results in downregulation of these CAs in normoxia, with a restoration of the hypoxic response. We found a binding site for hypoxia inducible factor $1 \alpha(\mathrm{HIF}-1 \alpha)$, the hypoxia response element (HRE) in the CA9 promoter and demonstrated that hypoxic induction is absent in cell lines defective for the HIF pathway, but may be restored by transfection of human HIF-1 $\alpha$. Mutations made within the core of the HRE also abrogate the hypoxic response, confirming the pivotal role of the HIF pathway (Wykoff et al, 2000). The strong inducibility in hypoxia that is conferred by the minimal CA9 promoter may be of use in targeting gene therapy vectors to areas of tumour hypoxia (Dachs et al, 1997). Other factors may be of significance in producing the strong upregulation of CAIX in cancer, since p53 mutation modulates expression, the promoter is less methylated in cancer (Cho et al, 2001) and contains binding sites for activator protein 1 and specificity protein transcription factors 1 and 3 (Kaluzova et al, 2001).

Other HIF target genes include glucose transporters, glycolytic enzymes and angiogenic growth factors such as VEGF, all essential for survival in a hostile, hypoxic environment. The tumourassociated CAs may play a role in maintenance of an acidic extracellular $\mathrm{pH}$, an important element of the malignant phenotype (Ivanov et al, 2001). Although lactate produced by glycolysis under hypoxic conditions is a significant contributor to acidic extracellular $\mathrm{pH}$, there is also a substantial contribution from carbonic acid (Griffiths et al, 2001).

\section{CAIX AS A MARKER OF HYPOXIA}

Hypoxic tumours are known to have a relatively poor prognosis, independent of the modality of treatment used (Vaupel, 1997). Current methods of measuring tumour oxygenation are either invasive (Eppendorf microelectrode) or require administration of chemical agents (e.g. pimonidazole). There are obvious benefits of an endogenous hypoxia biomarker that is nondiffusible (unlike VEGF) and easily processed in paraffin sections for staining. Thus, it is important to demonstrate that the in vitro findings with regard to $\mathrm{CA}$ induction by hypoxia can be confirmed in vivo.

In a multicellular spheroid model, CAIX immunostaining was more marked on the plasma membrane of cells from the innermost layers, with a distribution similar to that of pimonidazole. Similarly, human glioma xenografts grown in immunodeficient mice show more CAIX-staining in poorly perfused and hypoxic areas. The CAIX-stained cells remained viable when plated out, and were shown to be more radioresistant than unstained cells (Olive et al, 2001).

In vivo studies in human tumours have confirmed these findings, revealing a predominantly perinecrotic staining pattern. In squamous cancers of the head and neck, we observed a gradient of CA9 expression with highest levels adjacent to frank necrosis and considerable overlap with pimonidazole staining (Beasley et al, 2001). Biopsies of invasive cervical carcinomas also showed a good correlation between staining for the two hypoxia markers, CA9 staining being more extensive in almost all cases (Olive et al, 2001).

CD34 staining of the microvasculature reveals a median distance of $80 \mu \mathrm{m}$ between a vessel and CAIX expression in squamous head and neck tumours, which corresponds to a tissue oxygen tension of around $1 \%$. This corresponds to the level at which HIF- $1 \alpha$ and its target genes are induced. In this study, CAIX staining was also significantly related to levels of tumour necrosis (Beasley et al, 2001).

Papillary renal tumours, breast, bladder and ovarian cancers show a similar perinecrotic CAIX distribution. Conversely, renal clear cell carcinomas showed a uniform staining pattern irrespective of areas of hypoxia and necrosis, suggesting a constitutively upregulated HIF pathway in these tumours (Wykoff et al, 2000).

Definitive measurement of tumour hypoxia by Eppendorf microelectrode has confirmed that there is a significant positive correlation between the hypoxic fraction of advanced cervical carcinomas and the extent of CAIX immunostaining (Loncaster et al, 2001). Whether the above findings will translate to significant prognostic information in a prospective trial remains to be determined, but accumulating evidence from a number of clinical studies (see Table 2) suggests that this may indeed be the case.

\section{CARBONIC ANHYDRASE AS A TARGET FOR THERAPY}

Further evidence of the importance of the CAs in the oncogenic process comes from the use of CA inhibitors, most notably the heterocyclic and aromatic sulphonamides of which acetazolamide is the most prominent.

In bicarbonate-free medium, sulphonamides were effective in reducing growth rates of lymphoma cell lines according to their order of potency in CA inhibition (Chegwidden et al, 2000). The growth inhibition was reversed by supplementing the medium with nucleotide precursors, suggesting that these may be depleted most readily by the high metabolic flux of the transformed cell in a low bicarbonate environment. The critical step may involve carbamoyl synthetase II, a cytosolic enzyme that utilises bicarbonate for the first step in pyrimidine nucleotide biosynthesis.

Many novel sulphonamide derivatives have been shown to have growth-inhibitory effects on a variety of malignant cell lines in vitro, often at concentrations in the nanomolar range (Supuran et al, 2001). However, some sulphonamides without any CAinhibitory activity also show growth-inhibitory effects, possibly because of inhibition of tubulin polymerisation. There is also potentially a degree of crossover with inhibition of other zinc metalloenzymes, notably the matrix metalloproteinases.

Acetazolamide has been shown to reduce invasiveness of four RCC cell lines in vitro by $18-74 \%$, although the only cell line shown to express CAIX was also the least affected (Parkkila et al, $2000 \mathrm{~b}$ ). The concentrations used were orders of magnitude greater than that needed to inhibit CA.

Invasiveness is known to increase in cells cultured in low $\mathrm{pH}$ medium, and it is possible that the presence of CA activity may promote this acidification of the extracellular space, with 
Table 2 Expression of membrane-associated CAs in human tumours

\begin{tabular}{|c|c|}
\hline Tumour & CA expression pattern \\
\hline Cervical & $\begin{array}{l}\text { CAIX expressed in majority cervical squamous cell carcinomas, significant independent negative predictor of survival (Loncaster et al, 200 I). } \\
\text { Expression in smear parallels that of tissue biopsies and correlates with clinically significant disease at biopsy (Liao and Stanbridge, 2000). }\end{array}$ \\
\hline $\begin{array}{l}\text { Squanous carcinoma of } \\
\text { the head and neck } \\
\text { Lung }\end{array}$ & $\begin{array}{l}\text { CAIX Immunostaining perinecrotic and associated with advanced disease (Beasley et al, } 200 \mathrm{I} \text { ), poor radiosensitivity and short survival } \\
\text { (Koukourakis et al, 200 I). } \\
\text { Fifty percent squamous carcinoma and I6\% adenocarcinomas express CAIX (O'Byrne et al, 200 I), absent in dysplastic (Vermylen et al, 1999) } \\
\text { and normal tissues.Expression increases with advanced stage disease and is a significant adverse prognostic factor (Giatromanolaki et al, 200I). }\end{array}$ \\
\hline Breast & $\begin{array}{l}\text { Fifty percent ductal carcinoma-in situ and } 29 \% \text { invasive carcinomas positive for CAIX immunostaining, associated with necrosis, high-grade and } \\
\text { poor prognosis. (Chia et al, 200 I) CAXII staining found in } 89 \% \text { normal breast samples, } 84 \% \text { DCIS and } 7 \text { I\% invasive carcinomas, associated with } \\
\text { low-grade and good prognosis. (Wykoff et al, 200I) }\end{array}$ \\
\hline Colorectal & $\begin{array}{l}\text { CAIX exspression parallels cellular proliferation and increases with reduced cellular differentiation being more pronounced in frank } \\
\text { adenocarcinoma than dysplasia or adenomatous disease (Saarnio et al, 1998). CAXIl expression is also increased in adenocarcinoma (Kivela et al, } \\
\text { 2000a) }\end{array}$ \\
\hline
\end{tabular}

Beasley NJ, Wykoff CC, Watson PH, Leek R, Turley H, Gatter K, Pastorek J, Cox GJ, Ratcliffe P, Harris AL (200I) Carbonic anhydrase IX, an endogenous hypoxia marker, expression in head and neck squamous cell carcinoma and its relationship to hypoxia, necrosis, and microvessel density. Cancer Res 61: 5262-5267

Chia SK, Wykoff CC, Watson PH, Han C, Leek RD, Pastorek J, Gatter KC, Ratcliffe P, Harris AL (200 I) Prognostic significance of a novel hypoxia-regulated marker, carbonic anhydrase ix, in invasive breast carcinoma. J Clin Oncol 19: 3660-3668

de la Taille A, Buttyan R, Katz AE, McKiernan J, Burchardt M, Burchardt T, Chopin DK, Sawczuk IS (2000) Biomarkers of renal cell carcinoma. Past and future considerations. Urol Oncol 5: $139-148$

Divgi CR, Bander NH, Scott AM, O'Donoghue JA, Sgouros G, Welt S, Finn RD, Morrissey F, Capitelli P, Williams JM, Deland D, Nakhre A, Oosterwijk E, Gulec S, Graham MC, Larson SM, Old LJ (1998) Phase I/II radioimmunotherapy trial with iodine- I3I-labeled monoclonal antibody G250 in metastatic renal cell carcinoma. Clin Cancer Res 4: 2729 2739

Giatromanolaki A, Koukourakis MI, Sivridis E, Pastorek J, Wykoff CC, Gatter KC, Harris AL (200I) Expression of hypoxia-inducible carbonic anhydrase-9 relates to angiogenic pathways and independently to poor outcome in non-small cell lung cancer. Cancer Res 61: 7992-7998

Kivela A, Parkkila S, Saarnio J, Karttunen T], Kivela J, Parkkila AK, Waheed A, Sly WS, Grubb JH, Shah G, Tureci O, Rajaniemi H (2000a) Expression of a novel transmembrane carbonic anhydrase isozyme XII in normal human gut and colorectal tumors. Am J Pathol I56: 577-584

Kivela AJ, Parkkila S, Saarnio J, Karttunen T], Kivela J, Parkkila AK, Pastorekova S, Pastorek J, Waheed A, Sly WS, Rajaniemi H (2000b) Expression of transmembrane carbonic anhydrase isoenzymes IX and XII in normal human pancreas and pancreatic tumours. Histochem Cell Biol I I 4: 197-204

Koukourakis MI, Giatromanolaki A, Sivridis E, Simopoulos K, Pastorek J. Wykoff CC, Gatter KC, Harris AL (200I) Hypoxia-regulated carbonic anhydrase-9 (CA9) relates to poor vascularization and resistance of squamous cell head and neck cancer to chemoradiotherapy. Clin Cancer Res 7: 3399-3403

Liao SY, Stanbridge EJ (2000) Expression of MN/CA9 protein in Papanicolaou smears containing atypical glandular cells of undetermined significance is a diagnostic biomarker of cervical dysplasia and neoplasia. Cancer 88: | |08-||2|

Loncaster JA, Harris AL, Davidson SE, Logue JP, Hunter RD, Wycoff CC, Pastorek J, Ratcliffe PJ, Stratford IJ, West CM (200 I) Carbonic anhydrase (CA IX) expression, a potential new intrinsic marker of hypoxia: correlations with tumor oxygen measurements and prognosis in locally advanced carcinoma of the cervix. Cancer Res 61: 6394-6399

O'Byrne KJ, Cox G, Swinson D, Richardson D, Edwards JG, Lolljee J, Andi A, Koukourakis Ml, Giatromanolaki A, Gatter K, Harris AL, Waller D, Jones JL (200I) Towards a biological staging model for operable non-small cell lung cancer. Lung Cancer 34: S83-S89

Parkkila S, Parkkila AK, Saarnio J, Kivela J, Karttunen TJ, Kaunisto K, Waheed A, Sly WS, Tureci O, Virtanen I, Rajaniemi H (2000) Expression of the membrane-associated carbonic anhydrase isozyme XII in the human kidney and renal tumors. J Histochem Cytochem 48: 1601 - I608

Pastorekova S, Parkkila S, Parkkila AK, Opavsky R, Zelnik V, Saarnio J, Pastorek J (1997) Carbonic anhydrase IX, MN/CA IX: analysis of stomach complementary DNA sequence and expression in human and rat alimentary tracts. Gastroenterology I I 2: 398-408

Saarnio J, Parkkila S, Parkkila AK, Haukipuro K, Pastorekova S, Pastorek J, Kairaluoma MI, Karttunen TJ (1998) Immunohistochemical study of colorectal tumors for expression of a novel transmembrane carbonic anhydrase, MN/CA IX, with potential value as a marker of cell proliferation. Am J Pathol I53: 279-285

Saarnio J, Parkkila S, Parkkila AK, Pastorekova S, Haukipuro K, Pastorek J, Juvonen T, Karttunen TJ (200 I) Transmembrane carbonic anhydrase, MN/CA IX, is a potential biomarker for biliary tumours. J Hepatol 35: 643-649

Turner JR, Odze RD, Crum CP, Resnick MB (1997) MN antigen expression in normal, preneoplastic, and neoplastic esophagus: a clinicopathological study of a new cancerassociated biomarker. Hum Pathol 28: 740-744

Turner KJ, Crew JP, Wykoff CC, Watson PH, Poulsom R, Pastorek J, Ratcliffe PJ, Cranston D, Harris AL (2002) The hypoxia-inducible genes VEGF and CA9 are differentially regulated in superficial vs invasive bladder cancer. Br J Cancer 86: 1276-1282

Vermylen P, Roufosse C, Burny A, Verhest A, Bosschaerts T, Pastorekova S, Ninane V, Sculier JP (1999) Carbonic anhydrase IX antigen differentiates between preneoplastic malignant lesions in non-small cell lung carcinoma. Eur Respir J 14: 806-8II

Wykoff CC, Beasley N, Watson PH, Campo L, Chia SK, English,R, Pastorek J, Sly WS, Ratcliffe P, Harris AL (200I) Expression of the hypoxia-inducible and tumor-associated carbonic anhydrases in ductal carcinoma in situ of the breast. Am J Pathol I58: $1011-1019$

Wykoff CC, Beasley NJ, Watson PH, Turner KJ, Pastorek J, Sibtain A, Wilson GD, Turley H, Talks KL, Maxwell PH, Pugh CW, Ratcliffe PJ, Harris AL (2000) Hypoxia-inducible expression of tumor-associated carbonic anhydrases. Cancer Res 60: 7075-7083

concomitant activation of enzymes required for matrix degradation (Martinez-Zaguilan et al, 1996).

Acetazolamide has shown antitumour properties in a murine fibrosarcoma model, producing significant growth delays when used as a single agent, and additive growth delays in combination with a number of chemotherapeutic agents (Teicher et al, 1993).
In the clinical setting, the differential expression of CAIX in renal cancers has provided a target for radioimmunotherapy, antibody-mediated gene transfer and vaccination strategies (Tso et al, 2001), and phase I/II trial results with iodine-131 labelled murine monoclonal antibodies have been performed with some antitumour activity (Divgi et al, 1998). The development of a 
humanised monoclonal antibody is awaited to allow repeated cycles of treatment.

Many chemotherapeutic drugs are weak acids or bases, their $\mathrm{pK}_{\mathrm{a}}$ 's being in the physiological range. As most of these drugs enter the cell by passive diffusion and the plasma membrane is relatively impermeable to ionised species, slight differences in $\mathrm{pH}$ on either side of the membrane may result in dramatic alterations in the distribution of the drug due to ion trapping. In areas of tumour distant from the vasculature, extracellular $\mathrm{pH}$ may be expected to drop, whereas the intracellular $\mathrm{pH}$ remains relatively constant, increasing the intra- to extracellular $\mathrm{pH}$ gradient and favouring the uptake of weak acid drugs. Many clinically useful chemotherapeutic drugs are weak bases (e.g. doxorubicin, bleomycin, mitoxantrone), whose uptake in animal models may be enhanced by bicarbonate administration, reducing the extracellular acidity of tumours (Raghunand and Gillies, 2001). Whether CA inhibitors may be effective in reducing this tumour acidity and consequently have a role in combination chemotherapy remains to be demonstrated.

\section{CONCLUSIONS}

The intracellular $\mathrm{pH}$ in solid tumours remains close to the physiological value despite the relative acidity of the interstitial space under these circumstances, suggesting that malignant cells extrude protons more avidly than their untransformed counterparts. Studies on retinal pigmented epithelia have demonstrated a drop in intracellular $\mathrm{pH}$ following selective inhibition of extracellular CA by a membrane-impermeant agent, associated with reduced activity of the NHE (Wu et al, 1998). Similar effects have been seen in muscle, with reduced proton and lactate export when extracellular CA is inhibited (Geers and Gros, 2000). Acetazolamide will also inhibit activity of the AE,1 a protein functionally and physically linked to CAII and critical to maintaining cytoplasmic $\mathrm{pH}$ (Sterling et al, 2001). Both NHE and AE expression is also modulated by the HIF pathway (Karumanchi et al, 2001).

Extracellular CA would appear to be in an ideal position to convert carbon dioxide diffused across the plasma membrane to protons and bicarbonate, the latter being transported back into the cell by the AE, forming a Jacobs-Stewart cycle (Figure 1B), with net extrusion of protons.

The consequent acidification of the extracellular space would in addition be permissive for invasion, and have an adverse effect on cell-mediated immunity. Hypoxia-induced apoptosis may also be dependent on a drop in extracellular pH (Schmaltz et al, 1998) providing selective pressure for apoptosis-resistant malignant clones. The acidic microenvironment of tumours has long been assumed to be because of excess lactate production by anaerobic metabolism, but cells deficient in lactate production produce equally acidic interstiae (Griffiths et al, 2001) suggesting the importance of a distinct pathway for acidification such as that outlined above.

In addition to its role in transmembrane solute transport, extracellular CA may be important in facilitated diffusion of protons/carbon dioxide in the unstirred layers of the extracellular space. Rapid interconversion of the two species in the presence of mobile buffers will result in more rapid diffusion down the concentration gradient to better perfused areas, dissipating $\mathrm{pH}$ gradients that may otherwise preclude further tumour growth (Griffiths et al, 2001).

The presence of a proteoglycan/cell adhesion domain on the CAIX protein is highly suggestive of a role in cell-cell or cellmatrix interaction. The majority of CAIX expression in normal tissues would appear to be on the basolateral plasma membrane, and cell attachment to CAIX in vitro can be inhibited by monoclonal antibodies directed to this domain (Zavada et al, 2000). The cytoplasmic tail has not yet been shown to partake in a signal transduction pathway (unlike the RPTPs), but this has not been fully investigated.

As more is learnt about the mechanism of action of the tumourassociated CAs, it is hoped that they may make the transition from biomarkers of hypoxia and differentiation to essential tumour enzymes and therapeutic targets. The development of specific inhibitors for CAs IX and XII may facilitate this process, leading to a greater understanding of the role in tumour biology of these recently discovered yet phylogenetically ancient enzymes.

\section{REFERENCES}

Beasley NJ, Wykoff CC, Watson PH, Leek R, Turley H, Gatter K, Pastorek J, Cox GJ, Ratcliffe P, Harris AL (2001) Carbonic anhydrase IX, an endogenous hypoxia marker, expression in head and neck squamous cell carcinoma and its relationship to hypoxia, necrosis, and microvessel density. Cancer Res 61: $5262-5267$

Chegwidden WR, Dodgson SJ, Spencer IM (2000) The roles of carbonic anhydrase in metabolism, cell growth and cancer in animals. Exs $343-$ 363

Cho M, Uemura H, Kim SC, Kawada Y, Yoshida K, Hirao Y, Konishi N, Saga S, Yoshikawa K (2001) Hypomethylation of the MN/CA9 promoter and upregulated MN/CA9 expression in human renal cell carcinoma. $\mathrm{Br} \mathrm{J}$ Cancer 85: $563-567$

Dachs GU, Patterson AV, Firth JD, Ratcliffe PJ, Townsend KM, Stratford IJ, Harris AL (1997) Targeting gene expression to hypoxic tumor cells. Nat Med 3: $515-520$

Divgi CR, Bander NH, Scott AM, O'Donoghue JA, Sgouros G, Welt S, Finn RD, Morrissey F, Capitelli P, Williams JM, Deland D, Nakhre A, Oosterwijk E, Gulec S, Graham MC, Larson SM, Old LJ (1998) Phase I/II radioimmunotherapy trial with iodine-131-labeled monoclonal antibody G250 in metastatic renal cell carcinoma. Clin Cancer Res 4: $2729-2739$

Geers C, Gros G (2000) Carbon dioxide transport and carbonic anhydrase in blood and muscle. Physiol Rev 80: 681-715

Griffiths JR, McIntyre DJ, Howe FA, Stubbs M (2001) Why are cancers acidic? A carrier-mediated diffusion model for $\mathrm{H}+$ transport in the interstitial fluid. Novartis Found Symp 240: 46-62, discussion 62-7, $152-153$

Gut MO, Parkkila S, Vernerova Z, Rohde E, Zavada J, Hocker M, Pastorek J, Karttunen T, Gibadulinova A, Zavadova Z, Knobeloch KP, Wiedenmann B, Svoboda J, Horak I, Pastorekova S (2002) Gastric hyperplasia in mice with targeted disruption of the carbonic anhydrase gene Car9. Gastroenterology 123: $1889-1903$

Henry RP, Swenson ER (2000) The distribution and physiological significance of carbonic anhydrase in vertebrate gas exchange organs. Respir Physiol 121: 1-12

Ivanov S, Liao SY, Ivanova A, Danilkovitch-Miagkova A, Tarasova N, Weirich G, Merrill MJ, Proescholdt MA, Oldfield EH, Lee J, Zavada J, Waheed A, Sly W, Lerman MI, Stanbridge EJ (2001) Expression of hypoxia-inducible cell-surface transmembrane carbonic anhydrases in human cancer. Am J Pathol 158: 905-919

Ivanov SV, Kuzmin I, Wei MH, Pack S, Geil L, Johnson BE, Stanbridge EJ, Lerman MI (1998) Down-regulation of transmembrane carbonic anhydrases in renal cell carcinoma cell lines by wild-type von Hippel Lindau transgenes. Proc Natl Acad Sci USA 95: 12596-12601

Kaluzova M, Pastorekova S, Svastova E, Pastorek J, Stanbridge EJ, Kaluz S (2001) Characterization of the MN/CA 9 promoter proximal region: a role for specificity protein (SP) and activator protein 1 (AP1 factors. Biochem J 359: 669-677

Karumanchi SA, Jiang L, Knebelmann B, Stuart-Tilley AK, Alper SL, Sukhatme VP (2001) VHL tumor suppressor regulates Cl-/HCO 
3 -exchange and $\mathrm{Na}+/ \mathrm{H}+$ exchange activities in renal carcinoma cells. Physiol Genomics 5: $119-128$

Lieskovska J, Opavsky R, Zacikova L, Glasova M, Pastorek J, Pastorekova S (1999) Study of in vitro conditions modulating expression of MN/CA IX protein in human cell lines derived from cervical carcinoma. Neoplasma 46: $17-24$

Loncaster JA, Harris AL, Davidson SE, Logue JP, Hunter RD, Wycoff CC, Pastorek J, Ratcliffe PJ, Stratford IJ, West CM (2001) Carbonic anhydrase (CA IX) expression, a potential new intrinsic marker of hypoxia: correlations with tumor oxygen measurements and prognosis in locally advanced carcinoma of the cervix. Cancer Res 61: 6394-6399

Martinez-Zaguilan R, Seftor EA, Seftor RE, Chu YW, Gillies RJ, Hendrix MJ (1996) Acidic $\mathrm{pH}$ enhances the invasive behavior of human melanoma cells. Clin Exp Metastasis 14: 176-186

Olive PL, Aquino-Parsons C, MacPhail SH, Liao SY, Raleigh JA, Lerman MI, Stanbridge EJ (2001) Carbonic anhydrase 9 as an endogenous marker for hypoxic cells in cervical cancer. Cancer Res 61: 8924-8929

Opavsky R, Pastorekova S, Zelnik V, Gibadulinova A, Stanbridge EJ, Zavada J, Kettmann R, Pastorek J (1996) Human MN/CA 9 gene, a novel member of the carbonic anhydrase family: structure and exon to protein domain relationships. Genomics 33: $480-487$

Parkkila S, Parkkila AK, Saarnio J, Kivela J, Karttunen TJ, Kaunisto K, Waheed A, Sly WS, Tureci O, Virtanen I, Rajaniemi H (2000a) Expression of the membrane-associated carbonic anhydrase isozyme XII in the human kidney and renal tumors. J Histochem Cytochem 48: $1601-1608$

Parkkila S, Rajaniemi H, Parkkila AK, Kivela J, Waheed A, Pastorekova S, Pastorek J, Sly WS (2000b) Carbonic anhydrase inhibitor suppresses invasion of renal cancer cells in vitro. Proc Natl Acad Sci USA 97: $2220-2224$

Pastorek J, Pastorekova S, Callebaut I, Mornon JP, Zelnik V, Opavsky R, Zat'ovicova M, Liao S, Portetelle D, Stanbridge EJ et al . (1994) Cloning and characterization of $\mathrm{MN}$, a human tumor-associated protein with a domain homologous to carbonic anhydrase and a putative helix - loop - helix DNA binding segment. Oncogene 9: $2877-2888$

Pastorekova S, Parkkila S, Parkkila AK, Opavsky R, Zelnik V, Saarnio J, Pastorek J (1997) Carbonic anhydrase IX, MN/CA IX: analysis of stomach complementary DNA sequence and expression in human and rat alimentary tracts. Gastroenterology 112: 398-408

Peles E, Nativ M, Campbell PL, Sakurai T, Martinez R, Lev S, Clary DO, Schilling J, Barnea G, Plowman GD et al (1995) The carbonic anhydrase domain of receptor tyrosine phosphatase beta is a functional ligand for the axonal cell recognition molecule contactin. Cell 82: 251-260

Raghunand N, Gillies RJ (2001) pH and chemotherapy. Novartis Found Symp 240: 199-211, discussion 265-268

Schmaltz C, Hardenbergh PH, Wells A, Fisher DE (1998) Regulation of proliferation-survival decisions during tumor cell hypoxia. Mol Cell Biol 18: $2845-2854$
Sly WS (2000) The membrane carbonic anhydrases: from $\mathrm{CO}_{2}$ transport to tumor markers. Exs 95-104

Sterling D, Reithmeier RA, Casey JR (2001) A transport metabolon. Functional interaction of carbonic anhydrase II and chloride/bicarbonate exchangers. J Biol Chem 276: $47886-47894$

Supuran CT, Briganti F, Tilli S, Chegwidden WR, Scozzafava A (2001) Carbonic anhydrase inhibitors: sulfonamides as antitumor agents? Bioorg Med Chem 9: $703-714$

Teicher BA, Liu SD, Liu JT, Holden SA, Herman TS (1993) A carbonic anhydrase inhibitor as a potential modulator of cancer therapies. Anticancer Res 13: $1549-1556$

Tripp BC, Smith K, Ferry JG (2001) Carbonic anhydrase: new insights for an ancient enzyme. J Biol Chem 276: $48615-48618$

Tso CL, Zisman A, Pantuck A, Calilliw R, Hernandez JM, Paik S, Nguyen D, Gitlitz B, Shintaku PI, de Kernion J, Figlin R, Belldegrun A (2001) Induction of G250-targeted and T-cell-mediated antitumor activity against renal cell carcinoma using a chimeric fusion protein consisting of G250 and granulocyte/monocyte-colony stimulating factor. Cancer Res 61: $7925-7933$

Tureci O, Sahin U, Vollmar E, Siemer S, Gottert E, Seitz G, Parkkila AK, Shah GN, Grubb JH, Pfreundschuh M, Sly WS (1998) Human carbonic anhydrase XII: cDNA cloning, expression, and chromosomal localization of a carbonic anhydrase gene that is overexpressed in some renal cell cancers. Proc Natl Acad Sci USA 95: 7608-7613

Vaupel PW (1997) The influence of tumor blood flow and microenvironmental factors on the efficacy of radiation, drugs and localized hyperthermia. Klin Padiatr 209: 243-249

Whittington DA, Waheed A, Ulmasov B, Shah GN, Grubb JH, Sly WS, Christianson DW (2001) Crystal structure of the dimeric extracellular domain of human carbonic anhydrase XII, a bitopic membrane protein overexpressed in certain cancer tumor cells. Proc Natl Acad Sci USA 98: $9545-9550$

Wingo T, Tu C, Laipis PJ, Silverman DN (2001) The catalytic properties of human carbonic anhydrase IX. Biochem Biophys Res Commun 288: 666669

Wu Q, Pierce Jr WM, Delamere NA (1998) Cytoplasmic pH responses to carbonic anhydrase inhibitors in cultured rabbit nonpigmented ciliary epithelium. J Membr Biol 162: $31-38$

Wykoff CC, Beasley NJ, Watson PH, Turner KJ, Pastorek J, Sibtain A, Wilson GD, Turley H, Talks KL, Maxwell PH, Pugh CW, Ratcliffe PJ, Harris AL (2000) Hypoxia-inducible expression of tumor-associated carbonic anhydrases. Cancer Res 60: 7075-7083

Zavada J, Zavadova Z, Pastorek J, Biesova Z, Jezek J, Velek J (2000) Human tumour-associated cell adhesion protein MN/CA IX: identification of M75 epitope and of the region mediating cell adhesion. Br J Cancer 82: $1808-1813$

Zavada J, Zavadova Z, Pastorekova S, Ciampor F, Pastorek J, Zelnik V (1993) Expression of MaTu-MN protein in human tumor cultures and in clinical specimens. Int J Cancer 54: 268-274 